\title{
An EBSD Study of Deformation and Recrystallization in Magnesium Alloys
}

\author{
G.W. Lorimer and L.W.F. Mackenzie \\ Materials Science Centre, School of Materials, University of Manchester, Grosvenor Street, \\ Manchester, M1 7HS, UK
}

In the extruded condition some magnesium alloys, such as AZ31 (Mg-3wt\%Al-1wt\%Mg), exhibit an asymmetry of tensile and compressive properties, while others, such as WE43 (Mg-4wt\%Y$2.25 \mathrm{wt} \% \mathrm{Nd}-1 \mathrm{wt} \% \mathrm{HRE}-0.6 \mathrm{wt} \% \mathrm{Zr}$ ) exhibit isotropic behaviour [1]. This difference has been related to the texture produced during extrusion[2] and twinning during compression but not in tension. Recrystallization during thermomechanical processing may alter or reduce the texture and modify the mechanical properties [3]. In the present paper results are presented which were obtained during an investigation of the deformation and recrystallization of alloy ZC71 $(\mathrm{Mg}-7 \mathrm{wt} \% \mathrm{Zn}-1 \mathrm{wt} \% \mathrm{Cu})$.

Sand cast ZC71 was received from Magnesium Elektron Ltd and homogenized for 24 hours at 435 ${ }^{\circ} \mathrm{C}$, hot rolled $15 \%$ at $400{ }^{\circ} \mathrm{C}$ and then re-homogenized for 24 hours at $435{ }^{\circ} \mathrm{C}$ in order to break-up the second phase formed in the cast alloy. The material was then deformed in a channel die to a true strain of 0.4 at a true strain rate of $10^{-4} \mathrm{~s}^{-1}$ at temperatures between 250 and $400{ }^{\circ} \mathrm{C}$. The alloy was homogenized for 24 hours at $435{ }^{\circ} \mathrm{C}$ prior to extrusion at $282{ }^{\circ} \mathrm{C}$ with an extrusion ratio of 17.7 at a speed of $2.05 \mathrm{~m} \mathrm{~min}^{-1}$. Optical microscopy and electron backscattered diffraction (EBSD) were used to characterize the microstructure of the alloy; EBSD was also used to determine the texture of the as-deformed and annealed material. Tensile and compressive strengths were determined using an Instron.

Twinning and nucleation of new grains occurred during deformation. Fig. 1 is an EBSD map of ZC71 following deformation in a channel die at $250{ }^{\circ} \mathrm{C}$ to a true strain of 0.4 at a true strain rate of $10^{-4} \mathrm{~s}^{-1}$. Dynamic recrystallization of new grains has occurred along a pre-existing boundary. Fig. 2 is an EBSD map showing the partially recrystallized microstructure of as-extruded ZC71. Small recrystallized grains surround unrecrystallized material. In ZC71 deformed in a channel die at $250{ }^{\circ} \mathrm{C}$ and extruded at $270{ }^{\circ} \mathrm{C}$ recrystallization occurred preferentially at pre-existing grain boundaries.

The ZC71 extruded at $270{ }^{\circ} \mathrm{C}$ had a tensile / compressive strength ratio of 1.15. ZC71 extruded and homogenized for 25 hours at $435^{\circ} \mathrm{C}$ had a tensile / compressive strength ratio of 1.26. Fig. 3 shows the texture of ZC71 extruded at $270{ }^{\circ} \mathrm{C}$. Fig. 4 shows the texture of ZC71 extruded and then homogenized at $435{ }^{\circ} \mathrm{C}$. The as-extruded ZC71 exhibited a $<10 \overline{1} 0>$ fibre texture; after annealing the $<10 \overline{1} 0>$ fibre texture had been replaced by a $<\overline{2} 110>$ fibre texture.

In $<10 \overline{1} 0>$ and $<\overline{2} 110>$ fibre textures the basal planes are aligned parallel to the extrusion direction and are unfavourably orientated for slip. Twinning is an important deformation mechanism; twinning during compression occurs at a lower yield stress than slip or twinning during tension, and this is probably responsible for the observed mechanical asymmetry in the extruded and annealed ZC71. 


\section{References}

[1] Lorimer et al., Proc. Int. Conf. on Magnesium, Beijing, China, (2004) IN PRESS.

[2] E.A Ball and P.B. Prangnell, Scripta Met. and Mat., 10 (1994) 111.

[3] F. J. Humphreys and M. Hatherly, Recrystallization and Related Annealing Phenomena, $2^{\text {nd }}$ ed, Elsevier, United Kingdom, 2004.

[4] This work was supported by the EPSRC and Magnesium Elektron Ltd. Discussions with Prof. F.J. Humphreys are gratefully acknowledged.

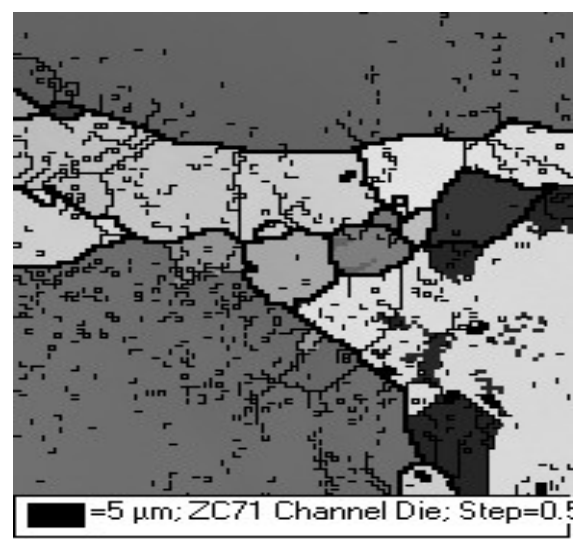

Fig. 1. EBSD map of ZC71 following channel die deformation at $250{ }^{\circ} \mathrm{C}$ to a true strain of 0.4 at a true strain rate of $10^{-4} \mathrm{~s}^{-1}$. Dynamic recrystallization of new grains has occurred along a pre-existing boundary.
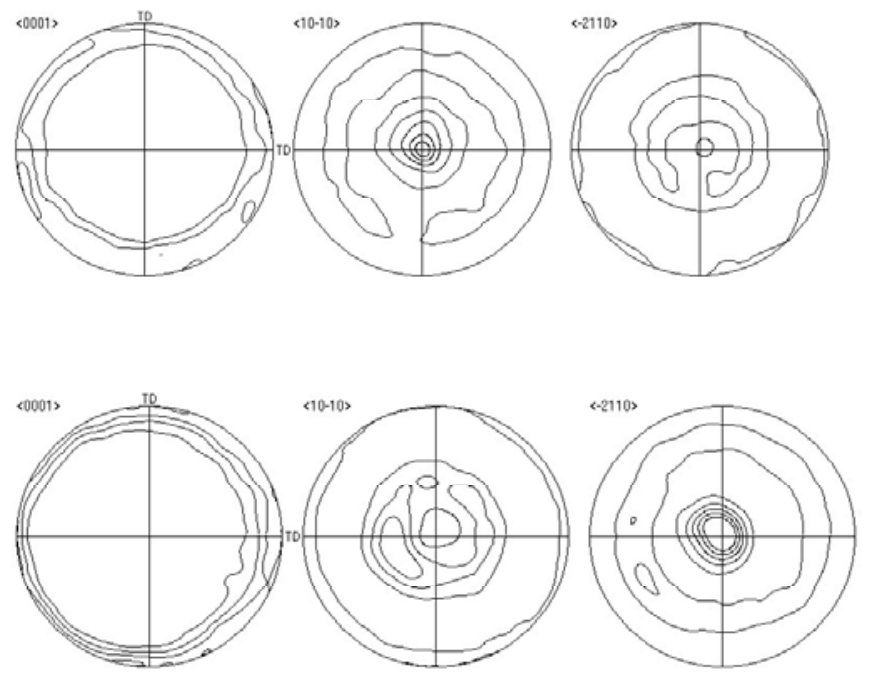

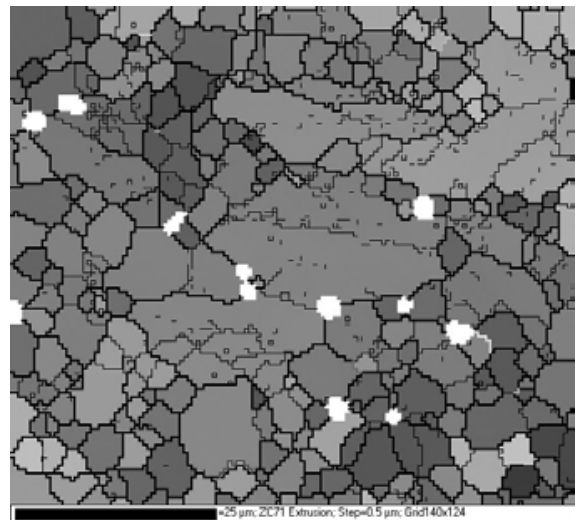

Fig. 2. EBSD map of ZC71 following extrusion at $270{ }^{\circ} \mathrm{C}$ with an extrusion ratio of 17.7 at a speed of $2.05 \mathrm{~m} \mathrm{~min}^{-1}$. Small recrystallized grains surround unrecrystallized material.

Fig. 3. $<10 \overline{1} 0>$ fibre texture of ZC71 following extrusion at $270{ }^{\circ} \mathrm{C}$

Fig. 4. $<\overline{2} 110>$ fibre texture of ZC71 following extrusion and annealing for 24 hours at $435{ }^{\circ} \mathrm{C}$ 